\title{
Epidemiology of canine gastrointestinal helminths in sub-Saharan Africa
}

\author{
Nozyechi Ngulube Chidumayo
}

\begin{abstract}
Background: Dogs have a close association with humans providing companionship, security and a source of dietary protein. However, dogs are also potential carriers of zoonotic pathogens. Dogs, therefore, pose a public health risk and a good understanding of canine diseases is important for planning and implementing control measures. The aim of this study was to characterise canine helminthiasis in sub-Saharan Africa using a systematic approach.

Methods: Pubmed and Google Scholar were searched for relevant primary studies published from 2000. Forty-one eligible studies were included in the meta-analysis. Pooled prevalences were estimated using the quality effects model.

Results and conclusions: Twenty-six genera of enteric helminths were reported and the pooled estimate of canine helminthiasis was 71\% (95\% Cl: 63-79\%). Species of Ancylostoma and Toxocara, causative agents of larva migrans in humans, were the most frequently reported helminths with pooled estimated prevalences of $41 \%$ (95\% Cl: 32-50\%) and 22\% (95\% Cl: 16-29\%), respectively. Dipylidium caninum and Taenia spp. were the most frequently reported cestodes with pooled estimated prevalences of 20\% (95\% Cl: 12-29\%) and 9\% (95\% Cl: 5-15\%), respectively. Trematodes were rarely reported. There was a high level of heterogeneity in most pooled estimates $\left(I^{2}>80 \%\right)$. The results of this study show that canine helminthiasis is highly prevalent in sub-Saharan Africa and there is need for regular deworming programmes to improve the health status of the dogs and minimise the potential health risk to humans.
\end{abstract}

Keywords: Dogs, Epidemiology, Helminths, Meta-analysis, Prevalence, Sub-Saharan Africa

\section{Background}

Dogs have a close association with humans providing companionship, security and protein [1]. However, dogs are also carriers of zoonotic pathogens including Toxocara canis and Ancylostoma spp. [1, 2]. Toxocara canis can cause diarrhoea, poor growth and death if present in large numbers in puppies [2]. Ancylostoma spp. are one of the most pathogenic helminths in dogs, especially puppies [2]. These nematodes are hematophagous and can cause anaemia and death if present in large numbers [2].

Canine zoonotic helminths pose a public health risk through environmental faecal contamination [3-5]. Canine and human infection with zoonotic canine helminths can occur through ingestion of the infective eggs and ingestion or skin penetration of the infective larvae [1, 2]. Human infection with Toxocara spp. is typically asymptomatic, however, some individuals develop visceral larva migrans and ocular toxocariasis $[1,2,6]$.

Correspondence: nozyechic@yahoo.com

Clinical Studies Department, School of Veterinary Medicine, University of Zambia, P. O. Box 32379 Lusaka, Zambia
Ancylostoma spp. are the aetiological agents of cutaneous larva migrans $[1,2]$ and Ancylostoma caninum has also been associated with eosinophilic enteritis in humans [7-10]. It is therefore important to understand the epidemiology of helminth infections in dogs to improve animal health and prevent the spread of zoonotic pathogens to humans.

The aim of this study was to characterise canine helminthiasis in sub-Saharan Africa and identify the most commonly reported helminths using a systematic approach.

\section{Methods}

\section{Literature search}

Pubmed and Google Scholar were systematically searched for publications from 2000 using the following search terms: dogs helminth, dogs helminthes, dogs helminths, dogs endoparasites, dogs gastrointestinal parasites, dogs gastro-intestinal parasites, dogs intestinal parasites, dogs enteric parasites, dog helminth, dog helminths, dog helminthes, dog endoparasites, dog gastro-intestinal parasites, 
dog gastrointestinal parasites, dog intestinal parasites, dog enteric parasites, canine helminth, canine helminths, canine helminthes, canine endoparasites, canine gastrointestinal parasites, canine gastro-intestinal parasites, canine intestinal parasites canine, enteric parasites, dogs nematodes, dog nematodes, canine nematodes, dogs cestodes, dog cestodes, canine cestodes, dogs trematodes, dog trematodes and canine trematodes. Title/abstract searches in Pubmed identified 786 articles. Title searches in Google Scholar identified 261 articles. The last search was conducted on 10th September 2016. Articles were stored in EndNote X5 (Thomson Reuters, New York, USA).

\section{Eligibility criteria}

The titles and abstracts were reviewed and articles were selected based on the following criteria: English language; full-text journal articles published from 2000; conducted in a country in sub-Saharan Africa; crosssectional or prospective studies. Articles were excluded if they did not report prevalence data, were case-control studies, clinical trials or pharmacological studies.

\section{Quality of the studies}

Eligible studies were assessed for quality of reporting and selection for bias using a quality assessment checklist [11, 12] (Additional file 1).

\section{Data extraction}

The following data were extracted where possible: location of the study, sample size, overall prevalence, genus and prevalence of detected helminths, sampling method, type of sample collected, sample processing and diagnostic method, age and sex of the dogs. For simplicity, dogs were characterised as puppies ( $\leq 6$ months), juveniles (> 6-12 months), immature ( $\leq 12$ months) and mature (>12 months). Relevant data was stored in Microsoft Excel.

\section{Data analysis}

MetaXL version 3.1 (http://www.epigear.com/), a tool for meta-analysis in Microsoft Excel, was used to pool prevalences from each study [13, 14]. Pooled estimated prevalences and their $95 \%$ confidence intervals (CI) were calculated using the quality effects model. The quality effects model uses quality scores to weigh studies according to sample size and study quality [13]. Pooled prevalence estimates were calculated for genera where prevalence data was extracted from a minimum of five studies. Heterogeneity among studies was evaluated by $\mathrm{I}^{2}$. $\mathrm{I}^{2}$ values of $25 \%, 50 \%$ and $75 \%$ were considered as having a low, moderate and high degree of heterogeneity, respectively [15]. Publication bias was assessed using funnel plots and doi plots. The symmetry of the doi plots was evaluated using the LFK index. LFK index values within \pm 1 , exceeding \pm 1 but within \pm 2 , and exceeding \pm 2 were considered as having no asymmetry, minor asymmetry and major asymmetry, respectively [14].

Potential sources of heterogeneity were further assessed by arranging the studies in subgroups according to sex, age (puppy and juvenile or immature and mature) and geographical regions (East Africa, West Africa and southern Africa). Regional subgroup analysis was conducted for helminth genera reported in at least 50\% of the articles.

\section{Results}

\section{Characteristics of eligible studies}

A total of 41 articles [16-56] from eight countries were identified (Fig. 1) and included in this study. The sample size of individual studies ranged from 33 to 1000 dogs. The quality of the selected studies ranged from 1 to 9 . Additional file 2: Table S1 and Additional file 3: Figure S1 give an overview of characteristics of eligible studies. A total of 12,029 samples, consisting of 11,717 faecal samples and 312 intestinal samples were included in the study. All samples were analysed using microscopy and processed using flotation (39\%), sedimentation and flotation (39\%), Kato-Katz (10\%), sedimentation (5\%) and washing and decantation (2\%).

\section{Pooling and heterogeneity analyses}

Thirty-six and 39 articles reported the overall and genera prevalence respectively. Twenty-six genera of helminths were reported across the studies (Additional file 4: Figure S2). Nematodes were the most frequently reported helminths followed by cestodes and trematodes.

1047 articles identified through Pubmed ${ }^{\star}$ and Google Scholar searches **

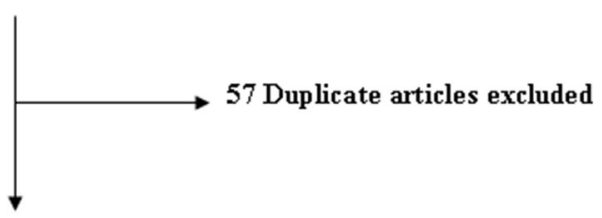

990 articles included in the title and abstract screening

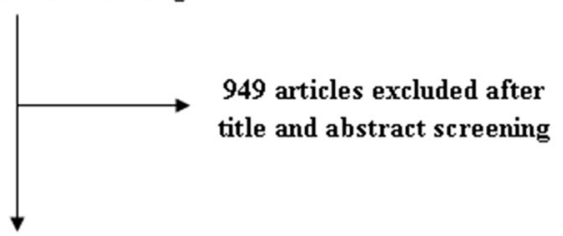

41 articles included in the analysis

Fig. 1 Flow chart of literature search and selection. *Title/abstract searches were conducted in Pubmed for articles published from 2000 to 2016. **Title searches were conducted in Google Scholar for articles published from 2000 to 2016. ${ }^{* *}$ The searches were limited to English pages and excluded patents and citations 
The overall prevalence of gastrointestinal helminths was 71\% (95\% CI: 63-79\%) among 11,343 dogs (Table 1 and Fig. 2). Southern Africa and East Africa had the highest prevalence of $81 \%$ (95\% CI: $68-93 \%)$ and $81 \%$ (95\% CI: 75-87\%), respectively, while West Africa had the lowest (59\%; 95\% CI: 47-70\%). Ancylostoma spp. were the most prevalent helminths (41\%; 95\% CI: 32-50\%), followed by Toxocara spp. (22\%; 95\% CI: 16-29\%) and Dipylidium caninum (20\%; 95\% CI: 12-29\%). Additional file 5: Figure S3 shows the forest plots of the estimated prevalences of the common helminth genera.

Sex and age prevalences are summarised in Table 2. The overall estimated pooled prevalence of gastrointestinal helminths in male dogs was 62\% (95\%: 45-78\%) while the prevalence in female dogs was 56\% (95\% CI: 40-71\%). Prevalence of helminths in immature and mature dogs were $74 \%$ (95\% CI: 56-89\%) and 62\% (95\% CI: 42-81\%), respectively. Juveniles had lower overall estimated pooled prevalence compared to puppies. In addition, estimated pooled prevalences of Ancylostoma spp. and
Toxocara spp. were lower in mature dogs compared to immature dogs. Additional file 6: Figure S4 and Additional file 7: Figure S5 show the forest plots of the estimated prevalences in the sex and age subgroups.

There was a high level of heterogeneity in most pooled estimates $\left(\mathrm{I}^{2}>80 \%\right)$ which could not be reduced with subgroup analysis by sub-region, age and sex. Assessment of the funnel plot and doi plot ruled out significant publication bias (Additional file 8: Figure S6).

\section{Discussion}

This study summarised the prevalence of canine gastrointestinal helminths in sub-Saharan Africa. The prevalence of canine helminths in sub-Saharan Africa is high with an estimated pooled prevalence of $71 \%$ (95\% CI: 63-79\%) across 36 studies. The high prevalence of gastrointestinal helminths may be due to inadequate deworming of dogs $[17,19,23,26,35,38,40,41,43,53]$. The highest prevalence was recorded for Ancylostoma spp. These findings are comparable with studies in Portugal [57],

Table 1 Estimated pooled prevalences of canine gastrointestinal helminths in sub-Saharan Africa

\begin{tabular}{|c|c|c|c|c|c|c|}
\hline Helminth & Region & Sample size & No. positive & Pooled prevalence & $95 \% \mathrm{Cl}$ & $1^{2}(\%)$ \\
\hline \multirow[t]{4}{*}{ Overall prevalence } & Sub-Saharan Africa & 11,343 & 7791 & 71 & $63-79$ & 98 \\
\hline & West Africa & 6550 & 3934 & 59 & $47-70$ & 98 \\
\hline & East Africa & 4068 & 3272 & 81 & $75-87$ & 95 \\
\hline & Southern Africa & 725 & 585 & 81 & $68-93$ & 90 \\
\hline \multirow[t]{4}{*}{ Ancylostoma spp. } & Sub-Saharan Africa & 11,214 & 4669 & 41 & $32-50$ & 99 \\
\hline & West Africa & 5876 & 1882 & 28 & $18-39$ & 98 \\
\hline & East Africa & 4514 & 2251 & 49 & $36-61$ & 98 \\
\hline & Southern Africa & 824 & 536 & 66 & $37-93$ & 97 \\
\hline \multirow[t]{4}{*}{ Toxocara spp. } & Sub-Saharan Africa & 11,420 & 2720 & 22 & $16-29$ & 98 \\
\hline & West Africa & 6346 & 1563 & 21 & $11-32$ & 99 \\
\hline & East Africa & 4250 & 1050 & 24 & $16-33$ & 97 \\
\hline & Southern Africa & 824 & 107 & 12 & $3-24$ & 90 \\
\hline \multirow[t]{4}{*}{ Dipylidium caninum } & Sub-Saharan Africa & 9717 & 1904 & 20 & $12-29$ & 99 \\
\hline & West Africa & 5570 & 684 & 10 & $3-20$ & 99 \\
\hline & East Africa & 3563 & 1137 & 32 & $25-38$ & 93 \\
\hline & Southern Africa & 584 & 83 & 11 & $0-55$ & 98 \\
\hline \multirow[t]{4}{*}{ Taenia spp. } & Sub-Saharan Africa & 6224 & 661 & 9 & $5-15$ & 97 \\
\hline & West Africa & 3481 & 324 & 7 & $3-11$ & 93 \\
\hline & East Africa & 1919 & 309 & 14 & $2-30$ & 99 \\
\hline & Southern Africa & 824 & 28 & 2 & $0-11$ & 96 \\
\hline Strongyloides spp. & Sub-Saharan Africa & 5398 & 1345 & 23 & $11-38$ & 99 \\
\hline Uncinaria stenocephala & Sub-Saharan Africa & 2083 & 283 & 7 & 0-39 & 99 \\
\hline Trichuris vulpis & Sub-Saharan Africa & 8692 & 883 & 5 & $2-10$ & 98 \\
\hline Spirocerca lupi & Sub-Saharan Africa & 2602 & 244 & 7 & $2-14$ & 96 \\
\hline Echinococcus spp. & Sub-Saharan Africa & 3087 & 162 & 5 & $3-7$ & 84 \\
\hline Toxascara spp. & Sub-Saharan Africa & 4040 & 192 & 3 & $1-7$ & 95 \\
\hline
\end{tabular}




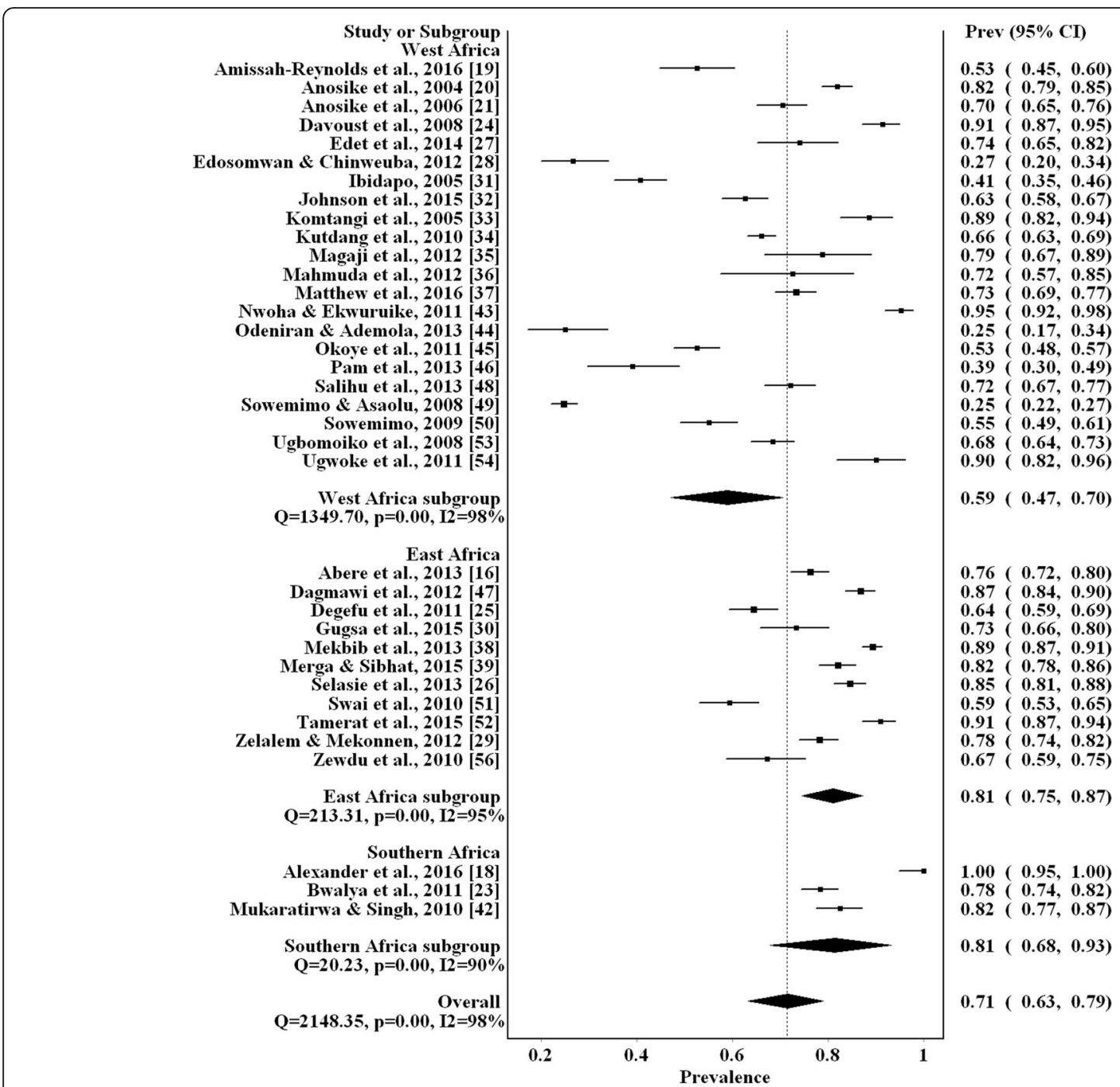

Fig. 2 Forest plot of the prevalence estimates of canine gastrointestinal helminths

Table 2 Estimated pooled prevalences of canine gastrointestinal helminths in sub-Saharan Africa by sex and age

\begin{tabular}{|c|c|c|c|c|c|c|}
\hline Helminth & Category & Sample size & No. positive & Pooled prevalence & $95 \% \mathrm{Cl}$ & $I^{2}(\%)$ \\
\hline \multirow[t]{6}{*}{ Overall prevalence } & Male & 4279 & 2569 & 62 & $45-78$ & 99 \\
\hline & Female & 2965 & 1547 & 56 & $40-71$ & 98 \\
\hline & Immature & 1932 & 1294 & 74 & $56-89$ & 98 \\
\hline & Mature & 3394 & 1975 & 62 & $42-81$ & 99 \\
\hline & Puppy & 400 & 247 & 71 & $45-91$ & 94 \\
\hline & Juvenile & 559 & 286 & 60 & $32-85$ & 97 \\
\hline \multirow[t]{2}{*}{ Ancylostoma spp. } & Immature & 1269 & 519 & 43 & $22-64$ & 98 \\
\hline & Mature & 1677 & 587 & 35 & $18-55$ & 98 \\
\hline \multirow[t]{2}{*}{ Toxocara spp. } & Immature & 1130 & 270 & 25 & $13-39$ & 95 \\
\hline & Mature & 1550 & 150 & 9 & $2-20$ & 97 \\
\hline
\end{tabular}


Mexico [58, 59], Brazil [60] and Argentina [61]. However, other studies in the Czech Republic [62], Poland [63], Canada [64], Denmark [65] and southern Wisconsin [66] reported Toxocara spp. as the most prevalent helminth. These findings suggest that Ancylostoma spp. and Toxocara spp. are more prevalent in the tropical/sub-tropical and temperate regions, respectively. Dipylidium caninum was the most prevalent cestode. This is in agreement with other studies conducted in China [26], Mexico [58, 59], Brazil [60] and Poland [63].

The estimated pooled prevalence of helminths in males was higher than in females. This result is not in agreement with other studies [58, 66-68]. A possible reason for the male-biased helminth prevalence may be the high Ancylostoma spp. prevalence. Male-biased Ancylostoma prevalences have been reported in some studies [61, 66, 69]. It is possible that male-biased helminth prevalence may occur when the prevalence of Ancylostoma spp. is higher than other helminths, as seen in this study. Another possible reason for the malebiased prevalence is the low deworming and neutering prevalences in the dog populations included in this study. Dogs in sub-Saharan Africa receive limited veterinary care and are irregularly dewormed and rarely neutered [26, 70]. Regular deworming and high neutering may significantly reduce the influence of sex on helminth susceptibility in studies that did not demonstrate male-biased prevalence. Unfortunately, the effect on sex on the prevalence of specific helminth genera could not be investigated as the data was not provided in the primary studies.

The overall estimated pooled prevalence of canine intestinal helminths was higher in young dogs than in adults. These results are in agreement with other studies that demonstrated a higher overall prevalence in young animals $[67,68,71]$. Higher prevalence in immature animals has been attributed to lower immune competence in this age group [69]. It would have been interesting to investigate the effect of both age and sex on helminth prevalence; however, this data was not reported in the primary studies.

This study has many limitations. First, the data displayed a large degree of heterogeneity across the studies across and sub-regions. Secondly, the studies were conducted in only eight countries: Nigeria, Ethiopia, Tanzania, Gabon, Ghana, Cameroon, Zambia and South Africa. Moreover, Nigeria and Ethiopia were overrepresented. Therefore, the results may not reflect the real situation in the region. The lack of studies from the majority of countries in sub-Saharan Africa may be due to limited research on canine diseases conducted in the region. Alternatively, it may be due to studies not being published in journals accessible online. Another limitation of this study is the incomplete information provided by some studies. For example, some studies provided limited information on study area while other studies did not report the helminths to species level; consequently, the results could not be further analysed to identify the source of the heterogeneity.

\section{Conclusions}

Despite the limitations of the study, the results indicate that the canine gastrointestinal helminths are highly prevalent in sub-Saharan Africa and there is a need for regular deworming programmes to improve the health status of the dogs and minimise the potential health risk to humans.

\section{Additional files}

\begin{abstract}
Additional file 1: Quality assessment checklist. (DOCX 14 kb)
Additional file 2: Table S1. Summary of studies included in the metaanalysis. (DOCX $43 \mathrm{~kb}$ )
\end{abstract}

Additional file 3: Figure S1. Frequency distribution of the characteristics of eligible studies. (TIFF $48 \mathrm{~kb}$ )

Additional file 4: Figure S2. Frequency distribution of canine gastrointestinal helminths. (TIFF $117 \mathrm{~kb}$ )

Additional file 5: Figure S3. Forest plots of the prevalence estimates. a Ancylostoma spp. b Toxocara spp. c Dipylidium caninum. d Taenia spp. e Strongyloides spp. f Uncinaria stenocephala. g Trichuris vulpis. h Spirocerca lupi. i Echinococcus spp. j Toxascara spp. k Overall prevalence. (TIFF 1424 kb)

Additional file 6: Figure S4. Forest plots of the prevalence estimates of gastrointestinal helminths in male (a) and female (b) dogs. (TIFF 217 kb)

Additional file 7: Figure S5. Forest plots of the prevalence estimates of gastrointestinal helminths in: a mature dogs; $\mathbf{b}$ immature dogs; $\mathbf{c}$ juveniles; d puppies. e Ancylostoma spp. in mature dogs. f Ancylostoma spp. in immature dogs. $\mathbf{g}$ Toxocara spp. in mature dogs. $\mathbf{h}$ Toxocara spp. in immature dogs. (TIFF $439 \mathrm{~kb}$ )

Additional file 8: Figure S6. Assessment of publication bias. a Funnel plot of the double arcsine transformed prevalence estimates of gastrointestinal helminths in dogs. $\mathbf{b}$ Doi plot the double arcsine transformed prevalence of gastrointestinal helminths in dogs (LFK index: 0.11). (TIFF $184 \mathrm{~kb}$ )

Additional file 9: Prevalence data sets. (XLSX $32 \mathrm{~kb}$ )

Acknowledgements

The author thanks, Dr Katendi Changula, a lecturer at The University of Zambia, School of Veterinary Medicine, for the moral support. The author is also grateful to anonymous reviewers for their meticulous reading of the paper.

Author's contribution

NNC conceived the idea and designed the study, performed the literature search and selection, extracted and analysed the data, wrote and revised the manuscript

\section{Funding}

Not applicable.

Availability of data and materials

All important datasets that support the conclusions of this article are included within the article and in Additional file 9.

Ethics approval and consent to participate

Not applicable.

Consent for publication

Not applicable. 


\section{Competing interests}

The author declares that she has no competing interests.

\section{Publisher's Note}

Springer Nature remains neutral with regard to jurisdictional claims in published maps and institutional affiliations.

\section{Received: 3 October 2017 Accepted: 30 January 2018} Published online: 20 February 2018

\section{References}

1. Beck A, Macpherson C, Meslin F, Wandeler A. The human-dog relationship: a tale of two species. In: MacPherson CNL, Meslin FX, Wandeler Al, editors. Dogs, zoonoses and public health. Oxon, New York: CABI Publishing; 2000 p. 1-16.

2. Overgaauw PA, van Knapen F. Dogs and nematode zoonoses. In: MacPherson CNL, Meslin FX, Wandeler Al, editors. Dogs, zoonoses and public health. Oxon, New York: CABI Publishing; 2000. p. 213-56.

3. Rubel D, Wisnivesky C. Magnitude and distribution of canine fecal contamination and helminth eggs in two areas of different urban structure, greater Buenos Aires, Argentina. Vet Parasitol. 2005;133:339-47.

4. Dubná S, Langrová I, Jankovská I, Vadlejch J, Pekár S, Nápravník J, et al. Contamination of soil with Toxocara eggs in urban (Prague) and rural areas in the Czech Republic. Vet Parasitol. 2007:144:81-6.

5. Habluetzel A, Traldi G, Ruggieri S, Attili A, Scuppa P, Marchetti R, et al. An estimation of Toxocara canis prevalence in dogs, environmental egg contamination and risk of human infection in the Marche region of Italy. Vet Parasitol. 2003;113:243-52.

6. Ahn SJ, Ryoo NK, Woo SJ. Ocular toxocariasis: clinical features, diagnosis, treatment, and prevention. Asia Pac Allergy. 2014;4:134-41.

7. Prociv P, Croese J. Human eosinophilic enteritis caused by dog hookworm Ancylostoma caninum. Lancet. 1990;335:1299-302.

8. Loukas A, Croese J, Opdebeeck J, Prociv P. Detection of antibodies to secretions of Ancylostoma caninum in human eosinophilic enteritis. Trans $R$ Soc Trop Med Hyg. 1992:86:650-3.

9. Croese J, Loukas A, Opdebeeck J, Prociv P. Occult enteric infection by Ancylostoma caninum: a previously unrecognized zoonosis. Gastroenterology. 1994;106:3-12.

10. Walker NI, Croese J, Clouston AD, Parry M, Loukas A, Prociv P. Eosinophilic enteritis in northeastern Australia. Pathology, association with Ancylostoma caninum, and implications. Am J Surg Pathol. 1995;19:328-37.

11. Ding H, Gao Y-M, Deng Y, Lamberton PH, Lu D-B. A systematic review and meta-analysis of the seroprevalence of Toxoplasma gondii in cats in mainland China. Parasit Vectors. 2017:10:27.

12. Tonouhewa ABN, Akpo Y, Sessou P, Adoligbe C, Yessinou E, Hounmanou $Y G$, et al. Toxoplasma gondii infection in meat animals from Africa: systematic review and meta-analysis of sero-epidemiological studies. Vet World. 2017;10:194.

13. Barendregt JJ, Doi SA, Lee YY, Norman RE, Vos T. Meta-analysis of prevalence. J Epidemiol Community Health. 2013;67:974-8.

14. Barendregt JJ, Doi SA. MetaXL User Guide Version 3.1. Queensland: Epigear International Pty Ltd; 2015.

15. Higgins J, Thompson SG, Deeks JJ, Altman DG. Measuring inconsistency in meta-analyses. BMJ. 2003;327:557-60.

16. Abere T, Bogale B, Melaku A. Gastrointestinal helminth parasites of pet and stray dogs as a potential risk for human health in Bahir Dar town, northwestern Ethiopia. Vet World. 2013;6:388-92.

17. Adedoja A, Oshodi JA, Akanbi AA, Babatunde S. Prevalence of intestinal protozoan parasites in stray and domicile dogs in Ilorin, north-central, Nigeria. Int J Biol Chem Sci. 2014;8:2054-61.

18. Alexander $\mathrm{AB}$, Poirotte $\mathrm{C}$, Porton IJ, Freeman $\mathrm{KL}$, Rasambainarivo $\mathrm{F}$, Olson $\mathrm{KG}$, et al. Gastrointestinal parasites of captive and free-living lemurs and domestic carnivores in eastern Madagascar. J Zoo Wildl Med. 2016;47:141-9.

19. Amissah-Reynolds PK, Monney I, Adowah LM, Agyemang SO. Prevalence of helminths in dogs and owners' awareness of zoonotic diseases in Mampong, Ashanti, Ghana. J Parasitol Res. 2016:2016:1715924.

20. Anosike J, Nwoke B, Ukaga C, Madu N, Dozie I. Aspects of intestinal helminth parasites of dogs in World Bank-assisted housing estate, New Oweri, Nigeria. Afr J Appl Zoo Environ Biol. 2004;6:25-9.
21. Anosike J, Ebiziem N, Ajero C, Asor J, Adeiyongo C, Bolaji O, et al. Prevalence and public health significance of helminth ova in deposited dog feces in Owerri, Nigeria. Anim Prod Res Adv. 2006;2:34-8.

22. Awoke $\mathrm{E}$, Bogale $\mathrm{B}$, Chanie $\mathrm{M}$. Intestinal nematode parasites of dogs: prevalence and associated risk factors. Int J Anim Vet Adv. 2011;3:374-8.

23. Bwalya EC, Nalubamba KS, Hankanga C, Namangala B. Prevalence of canine gastrointestinal helminths in urban Lusaka and rural Katete districts of Zambia. Prev Vet Med. 2011;100:252-5.

24. Davoust B, Normand T, Bourry O, Dang H, Leroy E, Bourdoiseau G. Epidemiological survey on gastro-intestinal and blood-borne helminths of dogs in north-east Gabon. Onderstepoort J Vet Res. 2008;75:359-64.

25. Degefu H, Tefera A, Yohannes M. Zoonotic helminth parasites in faecal samples of household dogs in Jimma town, Ethiopia. JPHE. 2011;3:138-43.

26. Selasie DG, Mesula G, Efriem D, Kassahun A, Solomon M. Gastrointestinal helminthes in dogs and community perception on parasite zoonosis at Hawassa city, Ethiopia. Glob Vet. 2013;11:432-40

27. Edet A, Itoro U, Theophilus J, Ekpenyong A, Imaobong U. Gastrointestinal parasites incidence and prevalence rate among dogs in Ibiono Ibom local government area, Akwa Ibom State, Nigeria. Curr Res Microbiol Biotechnol. 2014;2:289-91.

28. Edosomwan E, Chinweuba C. A survey on helminth parasites of dogs in Benin city, Edo State, Nigeria. JVMAH. 2012;4:56-60.

29. Zelalem G, Mekonnen A. Prevalence of gastrointestinal helminthes among dogs in Bahir Dar town, Ethiopia. WASJ. 2012;19:595-601.

30. Gugsa G, Hailu T, Kalayou S, Abebe N, Hagos Y. Study on gastrointestinal helminth parasites of dogs in Mekelle City, Tigray, Ethiopia. JPVB. 2015;7:29-36.

31. Ibidapo CA. Prevalence of intestinal helminth parasites of dogs in Lagos, Nigeria. Pak J Sci Ind Res. 2005:48:279

32. Johnson SA, Gakuya DW, Mbuthia PG, Mande JD, Maingi N. Prevalence of gastrointestinal helminths and management practices for dogs in the Greater Accra region of Ghana. Heliyon. 2015;1:e00023.

33. Komtangi MC, Mpoame M, Payne V, Ngufor M. Prevalence of gastrointestinal helminths of dogs in Dschang, Cameroon. JCAS 2005;5:11-4.

34. Kutdang E, Bukbuk D, Ajayi J. The prevalence of intestinal helminths of dogs (Canis familaris) in Jos, Plateau State, Nigeria. Researcher. 2010;2:51-6.

35. Magaji AA, Mohammed MN, Saulawa MA, Salihu MD. Survey of zoonotic gastrointestinal parasites of dogs (Canis familiaris) slaughtered at Zuru area, Kebbi State, Nigeria. SJVA. 2012;1:132-6.

36. Mahmuda A, Magaji AA, Yakubu Y, Salihu MD, Lawal MD, Mahmud U, et al. Prevalence of intestinal parasites of dogs slaughtered at Mami market area, Sokoto, Nigeria. SJAS. 2012;1:126-30.

37. Matthew TT, Seer IJ, David OK. The prevalence of gastrointestinal helminths $(\mathrm{GIH})$ infection of dogs in Makurdi metropolis. IJIR. 2016;2:1042-9.

38. Mekbib B, Regassa A, Sheferaw D. Gastrointestinal helminthes of dogs and owners' perception of dogs parasitic zoonoses in Hawassa, southern Ethiopia. JVMAH. 2013;5:20-6.

39. Merga T, Sibhat B. Prevalence of gastrointestinal helminth parasites of dogs and associated risk factors in Adama town, Central Ethiopia. Ethiop Vet J. 2015:19:91-103.

40. Minnaar WN, Krecek RC. Helminths in dogs belonging to people in a resource-limited urban community in Gauteng, South Africa. Onderstepoort J Vet Res. 2001;68:111-7.

41. Minnaar WN, Krecek RC, Fourie LJ. Helminths in dogs from a peri-urban resource-limited community in Free State Province, South Africa. Vet Parasitol. 2002;107:343-9.

42. Mukaratirwa S, Singh VP. Prevalence of gastrointestinal parasites of stray dogs impounded by the Society for the Prevention of Cruelty to Animals (SPCA), Durban and coast, South Africa. J S Afr Vet Assoc. 2010;81:123-5.

43. Nwoha R, Ekwuruike J. Prevalence of gastrointestinal parasites in dogs from Umuahia City of Abia State. GJMR. 2011;9:34-42.

44. Odeniran PO, Ademola 1O. Prevalence of zoonotic gastrointestinal helminth in dogs and knowledge of risk of infection by dog owners in Ibadan. Nigeria NVJ. 2013;34:851-8

45. Okoye IC, Obiezue NR, Okorie CE, Ofoezie IE. Epidemiology of intestinal helminth parasites in stray dogs from markets in south-eastern Nigeria. $J$ Helminthol. 2011:85:415-20.

46. Pam V, Igeh C, Hassan A, Udokaninyene A, Kemza S, Bata S, et al. Prevalence of haemo and gastrointestinal parasites in dogs in Vom, Jos south local government, Plateau State. JVA. 2013;3:74-8. 
47. Dagmawi P, Mekonnen A, Abebe F, Berhanu M. Prevalence of gastrointestinal helminthes among dogs and owners perception about zoonotic dog parasites in Hawassa town, Ethiopia. JPHE. 2012;4:205-9.

48. Salihu MD, Usman JA, Alhaji MA, Arikpo HA. Zoonotic gastrointestinal helminthes of household dogs in Sokoto, Nigeria. IJAVMS. 2013;7:50-6.

49. Sowemimo OA, Asaolu SO. Epidemiology of intestinal helminth parasites of dogs in Ibadan, Nigeria. J Helminthol. 2008;82:89-93.

50. Sowemimo OA. The prevalence and intensity of gastrointestinal parasites of dogs in Ile-lfe, Nigeria. J Helminthol. 2009;83:27-31.

51. Swai ES, Kaaya EJ, Mshanga DA, Mbise EW. A survey on gastro-intestinal parasites of non-descript dogs in and around Arusha municipality, Tanzania. IJAVA. 2010;2:63-7.

52. Tamerat N, Abera D, Teha R, Terefe Y, Lemma F. Cat and dog gastrointestinal helminth and assessment of community perception on helminthic zoonosis in Haramaya town, eastern Ethiopia. AEJSR. 2015;10:299-306.

53. Ugbomoiko US, Ariza L, Heukelbach J. Parasites of importance for human health in Nigerian dogs: high prevalence and limited knowledge of pet owners. BMC Vet Res. 2008;4:49.

54. Ugwoke EV, Audu PA, Umoh JU, Adakole JA. Prevalence of intestinal helminthes of dogs that have been disposed off at non-descript abattoirs in Zaria, Nigeria. BAJOPAS. 2011;4:44-7.

55. Yacob HT, Ayele T, Fikru R, Basu AK. Gastrointestinal nematodes in dogs from Debre Zeit, Ethiopia. Vet Parasitol 2007;148:144-148.

56. Zewdu E, Semahegn Y, Mekibib B. Prevalence of helminth parasites of dogs and owners awareness about zoonotic parasites in ambo town, central Ethiopia. Ethiop Vet J. 2010;14:17-30.

57. Ferreira F, Pereira-Baltasar P, Parreira R, Padre L, Vilhena M, Tavira LT, et al. Intestinal parasites in dogs and cats from the district of Évora, Portugal. Vet Parasitol. 2011;179:242-5.

58. Cantó G, García M, García A, Guerrero M, Mosqueda J. The prevalence and abundance of helminth parasites in stray dogs from the city of Queretaro in central Mexico. J Helminthol. 2011;85:263-9.

59. Eguia-Aguilar P, Cruz-Reyes A, Martinez-Maya J. Ecological analysis and description of the intestinal helminths present in dogs in Mexico City. Vet Parasitol. 2005;127:139-46.

60. Katagiri S, Oliveira-Sequeira T. Prevalence of dog intestinal parasites and risk perception of zoonotic infection by dog owners in Sao Paulo State, Brazil. Zoonoses Public Health. 2008:55:406-13.

61. Fontanarrosa MF, Vezzani D, Basabe J, An EDF. Epidemiological study of gastrointestinal parasites of dogs from southern greater Buenos Aires (Argentina): age, gender, breed, mixed infections, and seasonal and spatial patterns. Vet Parasitol. 2006;136:283-95.

62. Dubná S, Langrová I, Nápravník J, Jankovská I, Vadlejch J, Pekár S, et al. The prevalence of intestinal parasites in dogs from Prague, rural areas, and shelters of the Czech Republic. Vet Parasitol. 2007;145:120-8.

63. Tylkowska A, Pilarczyk B, Gregorczyk A, Templin E. Gastrointestinal helminths of dogs in western Pomerania, Poland. Wlad Parazytol. 2010;56:269-76.

64. Villeneuve A, Polley L, Jenkins E, Schurer J, Gilleard J, Kutz S, et al. Parasite prevalence in fecal samples from shelter dogs and cats across the Canadian provinces. Parasit Vectors. 2015;8:281.

65. Al-Sabi MN, Kapel CM, Johansson A, Espersen MC, Koch J, Willesen JL. A coprological investigation of gastrointestinal and cardiopulmonary parasites in hunting dogs in Denmark. Vet Parasitol. 2013;196:366-72.

66. Coggins JR. Effect of season, sex, and age on prevalence of parasitism in dogs from southeastern Wisconsin. J Helminthol Soc Wash. 1998;65:219-26.

67. Kirkpatrick CE. Epizootiology of endoparasitic infections in pet dogs and cats presented to a veterinary teaching hospital. Vet Parasitol. 1988;30:113-24

68. Gates MC, Nolan TJ. Risk factors for endoparasitism in dogs: retrospective case-control study of 6578 veterinary teaching hospital cases. J Small Anim Pract. 2009;50:636-40.

69. Miller T. Influence of age and sex on susceptibility of dogs to primary infection with Ancylostoma caninum. J Parasitol. 1965:701-4.

70. Kitala P, McDermott J, Kyule M, Gathuma J, Perry B, Wandeler A. Dog ecology and demography information to support the planning of rabies control in Machakos District, Kenya. Acta Trop. 2001;78:217-30.

71. Visco R, Corwin R, Selby L. Effect of age and sex on the prevalence of intestinal parasitism in dogs. J Am Vet Med Assoc. 1977;170:835-7.

\section{Submit your next manuscript to BioMed Central and we will help you at every step:}

- We accept pre-submission inquiries

- Our selector tool helps you to find the most relevant journal

- We provide round the clock customer support

- Convenient online submission

- Thorough peer review

- Inclusion in PubMed and all major indexing services

- Maximum visibility for your research

Submit your manuscript at www.biomedcentral.com/submit 